\title{
Retraction Note: Existence results for the general Schrödinger equations with a superlinear Neumann boundary value problem
}

\section{Zhen Liu ${ }^{1 *}$}

The original article can be found online at https://doi.org/10.1186/ s13661-019-1174-4

"Correspondence: zliu@ksu.edu.cn 1 School of Mathematics and Statistics, Kashi University, Kashi, China

\section{Retraction Note}

The Editors-in-Chief have retracted this article because it shows significant overlap with a previously published article by Guo and Ye [1] and an article by Meng that was simultaneously under consideration [2]. The author has not responded to correspondence regarding this retraction.

\section{Publisher's Note}

Springer Nature remains neutral with regard to jurisdictional claims in published maps and institutional affiliations.

Published online: 18 May 2021

\section{References}

1. Guo, Q., Ye, P.: Error analysis for lq-coefficient regularized moving least-square regression. J Inequal Appl 2018, 262 (2018). https://doi.org/10.1186/s13660-018-1856-y

2. Meng, B.: Minimal thinness with respect to the Schrödinger operator and its applications on singular Schrödinger-type boundary value problems. Bound Value Probl 2019, 91 (2019). https://doi.org/10.1186/s13661-019-1206-0

(c) The Author(s) 2021. This article is licensed under a Creative Commons Attribution 4.0 International License, which permits use, sharing, adaptation, distribution and reproduction in any medium or format, as long as you give appropriate credit to the original author(s) and the source, provide a link to the Creative Commons licence, and indicate if changes were made. The images or other third party material in this article are included in the article's Creative Commons licence, unless indicated otherwise in a credit line to the material. If material is not included in the article's Creative Commons licence and your intended use is not permitted by statutory regulation or exceeds the permitted use, you will need to obtain permission directly from the copyright holder. To view a copy of this licence, visit http://creativecommons.org/licenses/by/4.0/ 